\title{
Поетапна реконструкція аорти після розшаровуючої аневризми аорти I типу (за DeBakey)
}

\author{
Жеков І. І., Кравченко В. І., Черпак Б. В., Осадовська І. А., Хижняк К. А., Вайда В. В. \\ ДУ «Національний інститут серцево-судинної хірургії імені М. М. Амосова НАМН» (Київ)
}

\begin{abstract}
Розшарування аорти - це розрив у стінці аорти, що змушує кров текти між шарами стінки, відділяючи їх один від одного. Розшаровуюча аневризма є невідкладним станом, який може швидко призвести до смерті, навіть за оптимального лікування. Смертність унаслідок розриву сягає $80 \%$, а половина пацієнтів помирають ще до госпіталізації. Якщо збільшення аорти досягає в діаметрі 6 см і більше, пацієнт повинен бути прооперованим ургентно.
\end{abstract}

Мета роботи - представити клінічний випадок поетапної реконструкції аорти після розшаровуючої аневризми I типу (за DeBakey).

Матеріали та методи. У статті представлено клінічний випадок пацієнта з розшаровуючою аневризмою аорти I типу за класифікацією DeBakey та іï поетапною реконструкцією.

Результати та обговорення. Метою проведення хірургічного втручання є заміна висхідної аорти, щоб запобігти виникненню ретроградної дисекції і тампонади серця (основна причина смерті). Може бути виконана реконструкція аортального клапана або його ресуспензія. У випадках, коли структура аортального клапана порушена (синдром Марфана, двостулковий аортальний клапан), виконується його протезування.

Висновки. Вибір методу лікування залежить від типу розшарування та його впливу на інші органи та системи організму.

1. Пацієнтам із розшаруванням висхідної аорти потрібно виконувати оперативне втручання в екстреному порядку, контролювати АТ.

2. Пацієнти із розшаруванням низхідної аорти спочатку лікуються консервативно, із жорстким контролем АТ.

3. Медикаментозне лікування з подальшим ендопротезуванням грудної аорти наразі набуває поширеності при лікуванні гострих розшаровуючих аневризм аорти типу В.

Ключові слова: аортальна недостатність, супракоронарне протезування висхідної аорти, протезування дуги аорти, артеріальне переключення судин дуги аорти, процедура, «еlephant trunk» при хірургічному лікуванні розшаровуючої аневризми аорти I тип за класифікацією DeBakey.

Хвороби аорти належать до найбільш небезпечних патологій, що реєструють у відділеннях невідкладної допомоги. Загальний термін «гострий аортальний синдром» охоплює групу катастрофічних захворювань - розшарування аорти, аневризми аорти, інтрамуральну аортальну гематому, проникаючі атеросклеротичні виразки аорти, травми аорти та гострі запальні аневризми аорти.

Аневризма - незворотне розширення аорти, що перевищує їі нормальний діаметр для пацієнта даного віку і росту (D. Cooley, 1986; L. Svensson, E. Crawford, 1997). Як правило, наявність аневризми діагностують, якщо поперечний діаметр аорти більше нормального у півтора-два рази (М. Ergin, 1999; K. Johnston, 1991; L. Svensson, 1997). Слід також зазначити, що відбувається не тільки розширення аорти в діаметрі, а і іiї подовження на ділянці, ураженій аневризмою.

Розшарування аорти - це розрив у стінці аорти, що змушує кров текти між шарами стінки, відділяючи їх один від одного. Розшаровуюча аневризма є невідкладним станом, який може швидко призвести до смерті, навіть за оптимального лікування. Якщо розшаровуюча аневризма проходить через усі три шари, формується повний розрив стінки, відбувається величезна і швидка втрата крові.

Смертність унаслідок розриву сягає $80 \%$, а половина пацієнтів помирають ще до госпіталізації. Якщо збільшення аорти досягає в діаметрі 6 см і більше, пацієнт повинен бути ургентно прооперованим [7].

Аневризми аорти зустрічаються у будь-якому віці, але найчастіше виникають у людей віком 60-70 років. Загальна частота аневризм грудної аорти, встановлена за даними аутопсій, коливається в межах $0,9-1,4 \%$ усіх розтинів, із них аневризма висхідної аорти, за даними J. Bachet (1999), становить 45\%. Захворюваність у чоловіків удвічі вища, ніж у жінок. Приблизно $1,2 \%$ усіх чоловіків і 0,6\% усіх жінок помирають від аневризми аорти [8].

Симптоми розшаровуючої аневризми можуть імітувати перебіг інших хвороб, що часто призводить до затримок у діагностиці. Проте, коли розшаровуючі аневризми виявляють своєчасно і призначають адекватне 
хірургічне лікування, шанси пацієнта на виживання значно підвищуються.

Частота розшаровуючої аневризми: один випадок на 10000 госпіталізованих (проте значна частина хворих помирає на догоспітальному етапі); один випадок на 400 аутопсій; один хворий зі 100 померлих раптово. Загалом це 3-4\% випадків раптових смертей від серцево-судинних хвороб. Летальність від розшаровуючої аневризми становить 40-90\%. Кількість випадків розшаровуючої аневризми постійно збільшується. Без лікування рання смертність у разі розшарування становить $1 \%$ за годину в першу добу, 75\% - протягом 2 тижнів і понад 90\% - протягом першого року [1].

Існують дві класифікації - за DeBakey та Stanford, що базуються на анатомії розшарування або тривалості прояву симптомів до розшарування. Розшарування, що охоплює висхідну та/або дугу аорти, є невідкладним хірургічним станом, а розшарування низхідної аорти в гострому періоді лікується консервативно.

\section{Класифікація за DеBakey}

Видатний кардіохірург Michael Ellis DeBakey запропонував класифікацію, що передбачає анатомічний опис варіантів розшарування. Він розділяє розшарування залежно від місця і ступеня (локалізовані - висхідна або низхідна аорта; генералізовані - включають як висхідну, так і низхідну частини аорти):

- тип I - початок розшарування у висхідній частині аорти, далі поширюється на дугу і часто - дистально за її межі;

- тип II - обмежується висхідною аортою;

- тип III - початок у низхідній аорті, але поширюється дистально, рідко - проксимально.

\section{Стенфордська класифікація}

Згідно зі Стенфордською класифікацією (1970р.), розшарування аорти можна розподілити на дві групи - А і В, залежно від того, який відділ аорти ушкоджений. Група А включає висхідну аорту та/або дугу аорти i, можливо, низхідну аорту. Розшарування може відбуватися по висхідній аорті, дузі аорти або, рідше, в низхідній аорті. Вона включає розшарування аорти за DeBakey типу I, II i III з ретроградним продовженням у висхідну аорту (розшарування, що виникають у низхідній аорті або дузі аорти, але поширюються на висхідну аорту). Група В включає низхідну аорту (дистальне відходження лівої підключичної артерії) без участі висхідної аорти або дуги аорти. Вона включає розшарування аорти за DeBakey типу III без ретроградного продовження у висхідний відділ аорти [4, 7].

Серед основних симптомів розшарування аорти слід виділити:

- біль у грудній клітині. Раптово розпочинається напад сильного болю, що часто локалізується спереду та може переходити в міжлопатковий простір. Зазвичай надрив інтими супроводжується нестримним болем із самого початку його виникнення, на відміну від болю при інфаркті міокарда. Біль спереду грудини супроводжується розшаруванням висхідної аорти, а біль у міжлопатковій ділянці супроводжується розшаруванням низхідної аорти. Пацієнти описують біль як «пекучий, гострий, кинджальний» [6];

- серцева недостатність. Настає через виникнення гострої аортальної недостатності та/або інфаркту міокарда;

- пацієнти можуть поступати із симптомами та ознаками оклюзії однієї з гілок аорти. Серед них такі, як ішемічний інсульт або гостра ішемія нижніх кінцівок (виникає через стиснення або дисекцію); параплегія із сенсорними дефіцитами (оклюзія спинальної артерії); інфаркт міокарда (найчастіше вражається права коронарна артерія); ниркова недостатність і реноваскулярна гіпертензія [2, 6];

- біль у животі;

- розшарування аорти може протікати безболісно.

Ретельно зібраний анамнез, наявність артеріальної гіпертензії, шумів серця або захворювання аортального клапана, попередніх рентгенівських знімків органів грудної клітини може бути корисним для проведення диференційної діагностики.

Мета роботи - представити клінічний випадок поетапної реконструкції аорти після розшаровуючої аневризми аорти I типу (за DeBakey).

Матеріали та методи. У статті представлено клінічний випадок пацієнта з розшаровуючою аневризмою аорти I типу за класифікацією DeBakey та іiї поетапна реконструкція.

Результати і обговорення. Метою проведення хірургічного втручання є заміна висхідної аорти, щоб запобігти виникненню ретроградної дисекції та тампонади серця (основна причина смерті). Може бути виконана реконструкція аортального клапана або його ресуспензія. У випадках, коли структура аортального клапана порушена (синдром Марфана, двостулковий аортальний клапан), виконується його протезування.

Eman I-cупракоронарне протезування висхідної аорти.

Пацієнт Г., 1975 р. н., поступив 11.01.2015 р. у НІССХ імені М. М. Амосова з діагнозом: гостра розшаровуюча аневризма аорти I тип, виражена аортальна недостатність, гемоперикард.

3 анамнезу відомо, що 07.01.2015 р. виник різкий, кинджальний біль за грудиною з іррадіацією в спину, головний біль, втрата свідомості. Довготривала, нелікована гіпертонія (160/110 мм рт. ст.). У пацієнта синдром Марфана.

До операції ЕхоКГ: аортальний клапан - 3-стулковий, градієнт тиску 7; зворотний витік - виражений; діаметр аорти 2,5/4,9/5,5; діаметр дуги 2,6 см; діаметр низхідної грудної аорти 2,8 см; діаметр черевної аорти 2,6 см; КДО 160 мл, КСО - 79 мл, УО - 81 мл, ФВ - 55\%; по задній стінці ЛШ - 1,5 см; по правому контуру - 1 см рідини.

Після операції ЕхоКГ: аортальний клапан - 3-стулковий, градієнт тиску 10; зворотний витік - мінімаль- 
ний; діаметр аорти 2,5/2,8/3,0; КДО - 109 мл, КСО 39 мл, УО - 70 мл, ФВ - 64\%; вільна рідина в перикарді не візуалізується.

12.01.2015: операція виконувалася через серединну стернотомію. Розкрито перикард. Гемоперикард 400 мл гемолізованої крові. Канюльовані ліва стегнова артерія та обидві порожнисті вени. Підключений і запущений АШК. Перетиснуто аорту. Кардіоплегія - кустодіол ретроградно. Аневризма висхідної аорти (діаметр 5,5-6,0 см) розсічена поздовжньо. Циркулярне розшарування на 1,5 см вище аортального клапана. Аортальна недостатність за рахунок відриву комісур АК.

Судинним протезом Vascutek (d=28 мм, l=7 см) виконано супракоронарне протезування висхідної аорти з ресуспензією АК. Гідропроба - аортальний клапан компетентний. Профілактика повітряної емболії. Відновлено серцеву діяльність. Гемостаз. Операція завершена звичайним методом.

Післяопераційний період протікав без ускладнень. Пацієнт виписаний у задовільному стані.

Eman II - протезування дуги аорти за типом «еlephant trunk» та повне переключення судин дуги аорти.

Пацієнт Г., 1975 р. н., поступив 10.10.2016 р. у HICCX імені М. М. Амосова з діагнозом: с/п супракоронарного протезування висхідної аорти (12.01.2015).

До операції ЕхоКГ: аортальний клапан - 3-стулковий, градієнт тиску 5; зворотний витік - мінімальний; діаметр аорти 2,5/2,9/3,2; діаметр дуги: 4,5 см; діаметр низхідної грудної аорти 4,2 см; діаметр черевної аорти 6,0 см; КДО - 123 мл, КСО - 42 мл, УО - 81 мл, ФВ - 65\%.

Після операції ЕхоКГ: аортальний клапан - 3-стулковий, градієнт тиску 7; зворотний витік - мінімальний; діаметр аорти 2,5/2,8/3,0; діаметр дуги 3,0 см; діаметр низхідної грудної аорти $4,2 \mathrm{~cm}$; діаметр черевної аорти 6,0 см; КДО - 90 мл, КСО - 36 мл, УО - 54 мл, ФВ - $60 \%$.

17.10.2016: операція виконувалася через серединну стернотомію. Кардіоліз (с/п супракоронарного протезування висхідної аорти 12.01.2015). Канюльовані права стегнова артерія та обидві порожнисті вени. Підключений та запущений АШК. Перетиснуто аорту. Кардіоплегія - кустодіол ретроградно. В умовах глибокої гіпотермії (18 єС) та ретроградної церебральної перфузії (116 хв.) судинним протезом Vascutek (d=22 мм, $1=9$ см) виконано протезування дуги аорти за типом «elephant trunk» та судинним протезом Vascutek (d=12 мм, $1=6 \mathrm{~cm})$ виконано повне артеріальне переключення судин дуги аорти. Профілактика повітряної емболії. Знято затискач з аорти. Відновлено серцеву діяльність. Гемостаз. Операція завершена звичайним методом.

Післяопераційний період протікав без ускладнень. Пацієнт виписаний у задовільному стані.

Eman III - TEVAR (ендопротезування низхідної грудної аорти).

Пацієнт Г., 1975 р. н., поступив 23.12.2016 р. у НICCX імені М. М. Амосова з діагнозом: с/п супрако- ронарного протезування висхідної аорти (12.01.2015), с/п протезування дуги аорти за типом «elephant trunk» та з повним артеріальним переключенням судин дуги аорти (17.10.2016).

До операції ЕхоКГ: аортальний клапан - 3-стулковий, градієнт тиску 7; зворотний витік - мінімальний; діаметр аорти $2,5 / 2,9 / 3,2$; діаметр дуги 2,2 см; діаметр низхідної грудної аорти 4,2 см; діаметр черевної аорти $6,0 \mathrm{~cm}$; КДО - 148 мл, КСО - 59 мл, УО - 89 мл, ФВ - 60\%.

Після операції ЕхоКГ: аортальний клапан - 3-стулковий, градієнт тиску 7; зворотний витік - мінімальний; діаметр аорти 2,5/2,8/3,0; діаметр дуги 2,2 см; діаметр низхідної грудної аорти 3,2 см; діаметр черевної аорти $6,0 \mathrm{~cm}$, КДО - 140 мл, КСО - 60 мл, УО - 80 мл, ФВ - 63\%.

26.12.2016: було виконано TEVAR (Thoracic Endovascular Aortic Repair). За стандартною методикою доступом через a. femoralis dextra після серії ангіографій проведено ендопротезування низхідної грудної аорти.

Далі стандартним доступом системою RELAY NBS plus 270x40x32 мм виконано ендопротезування дистальної частини низхідної грудної аорти. Ангіографічний результат хороший, endoleaks немає, всі судини дуги, включно із лівою підключичною артерією, заповняються антеградно. Над вісцеральними судинами візуалізується фенестрація. Операція закінчена за звичайною методикою.

Висновки. Вибір методу лікування залежить від типу розшарування та його впливу на інші органи та системи організму.

1. Пацієнтам із розшаруванням висхідної аорти потрібно виконувати оперативне втручання в екстреному порядку, контролювати АТ.

2. Пацієнти із розшаруванням низхідної аорти спочатку лікуються консервативно, із жорстким контролем АТ.

3. Медикаментозне лікування з подальшим ендопротезуванням грудної аорти наразі набуває поширеності при лікуванні гострих розшаровуючих аневризм аорти типу $\mathrm{B}$.

\section{Література}

1. Ситар Л. Л. Аневризми грудної аорти. - 2011. - С. 83-89.

2. Elefteriades J. A., Rizzo J. A. Epidemiology: incidence, prevalence, and trends. In: Elefteriades J. A., editor. Acute Aortic Disease. - New York : Informa Healthcare, 2014. - P. 89-98.

3. Risk profiles for aortic dissection and ruptured or surgically treated aneurysms: A prospective cohort study / Landenhed M., Engstrцm G., Gottsдter A. et al. // J Am Heart Assoc. - 2015. - № 21. - e001513. DOI: 10.1161 / JAHA. 114.001513

4. Pokrovsky A. V. Incidence and prevalence of aortic diseases. In: Pokrovsky A. V., editors. Diseases of Aorta and Its Branches. 1st ed. - Moscow : Medicine, 1979. P. 326-327.

5. Medical Management of Acute Type A Aortic Dissection / Feldman M., Shah M., Elefteriades J. A. // Annals of Thoracic and Cardiovascular Surgery. - 2012. - Vol. 15. P. 286-293. PMID: 19901881 
6. Reoperations after previous surgery on the thoracic aorta: etiology, techniques and results / Carrel T., Tkebuchava T., Turina M. // Ann Thorac Surg. - 1993. - Vol. 56. - P. 259268. DOI: 10.1016/0003-4975(93)91157-I

7. Antegrade delivery of stent grafts to treat complex thoracic aortic disease / Roselli E. E., Soltesz E. G., Mastracci T. et al. // Ann Thorac Surg. - 2010. - Vol. 90. - P. 539-546. 10. 1016/j.athoracsur.2010.04.040

8. Lin C. H. Modified four-branched graft technique without circulatory arrest and antegrade thoracic endovascular aortic repair for extensive thoracic aorta reconstruction // Ann Thorac Surg. - 2014. - Vol. 94. - P. e159-e161. 10.1016/j.athoracsur.2012.08.084

\title{
Phased reconstruction of aorta after dissecting aortic aneurysm type I (by DeBakey)
}

\author{
Zhekov I. I., Kravchenko V. I., Cherpak B. V., Osadovska I. A., Khizhnyak K. A., Vayda V. V. \\ National M. M. Amosov Institute of Cardiovascular Surgery National Academy of Medical Sciences of Ukraine (Kyiv)
}

Aortic dissection - a tear in the aortic wall that causes blood to flow between the layers of the wall separating them from each other. Aortic dissection is an urgent condition that can quickly lead to death, even with optimal treatment. Mortality rate is up to $80 \%$, and half of the patients die before admission. If the aortic diameter reaches $6 \mathrm{~cm}$ or more, the patient should be operated urgently. The goal of the surgery is to replace the ascending aorta and to prevent retrograde dissection and cardiac tamponade (the main cause of death).

Objective. To present the clinical case of phased reconstruction of aorta after dissecting aortic aneurysm type I (by DeBakey).

Materials and Methods. The article presents clinical case of a patient with dissecting aortic aneurysm of type I (by DeBakey) classification and its gradual reconstruction.

Results and discussion. The goal of surgery is to replace the ascending aorta and to prevent retrograde dissection and cardiac tamponade (the main cause of death). Aortic valve reconstruction or it's resuspension can be performed. When the structure of the aortic valve is impaired (Marfan syndrome, bicuspid aortic valve) it should be replaced.

Conclusion. The choice of treatment depends on the type of dissection and its impact on other organs and body systems.

1. Patients with ascending aorta dissection require urgent surgery and control of blood pressure.

2. Patients with dissection in descending aorta are managed conservatively with tight control of blood pressure.

3. Drug treatment followed by thoracic aorta endoprosthesis nowadays is used in the management of acute aortic aneurysms type B.

Key words: aortic insufficiency, supracoronary replacement of ascending aorta, aortic arch prosthesis, switching procedure of blood vessels of the aortic arch, «elephant trunk» procedure.

\section{Поэтапная реконструкция аорты после расслаивающей аневризмы аорты I типа (по DeBakey)}

\author{
Жеков И. И., Кравченко В. И., Черпак Б. В., Осадовская И. А., Хижняк К. А., Вайда В. В. \\ ГУ «Национальный институт сердечно-сосудистой хирургии имени Н. М. Амосова НАМН» (Киев)
}

Расслоение аорты - это разрыв в стенке аорты, заставляющий кровь течь между слоями стенки, отделяя их друг от друга. Расслаивающая аневризма является неотложным состоянием, которое может быстро привести к смерти, даже при оптимальном лечении. Смертность вследствие разрыва достигает 80\%, а половина пациентов умирают еще до госпитализации. Если увеличение аорты достигает в диаметре 6 см и более, пациент должен быть прооперирован ургентно. Цель работы - представить клинический случай поэтапной реконструкции аорты после расслаивающей аневризмы I типа (по DeBakey).

Материалы и методы. В статье представлен клинический случай пациента с расслаивающей аневризмой аорты I типа по классификации DeBakey и ее поэтапной реконструкцией.

Результаты и обсуждение. Целью проведения хирургического вмешательства является замена восходящей аорты, чтобы предотвратить возникновение ретроградной диссекции и тампонады сердца (основная причина смерти). Может быть выполнена реконструкция аортального клапана или его ресуспензия. В случаях, когда структура аортального клапана нарушена (синдром Марфана, двустворчатый аортальный клапан), выполняется его протезирование.

Выводы. Выбор метода лечения зависит от типа расслоения и его влияния на другие органы и системы организма.

1. Пациентам с расслоением восходящей аорты нужно выполнять оперативное вмешательство в экстренном порядке, контролировать АД.

2. Пациентов с расслоением нисходящей аорты изначально лечат консервативно, при жестком контроле АД.

3. Медикаментозное лечение с последующим эндопротезированием грудной аорты в настоящее время все более распространяется при лечении острых расслаивающих аневризм аорты типа В.

Ключевые слова: аортальная недостаточность, супракоронарное протезирование восходящей аорты, протезирование дуги аорты, артериальное переключение сосудов дуги аорты, процедура «еlephant trunk» при хирургическом лечении расслаивающей аневризмы аорты I типа по классификации DeBakey. 